\title{
An environmentally and economically attractive integrated landform for the storage of tailings and waste at the Randalls Gold Project in Western Australia
}

\author{
D.A. Williams Golder Associates Pty Ltd, Australia \\ T.E. Minard Golder Associates Inc., United States of America
}

\begin{abstract}
The traditional approach that is commonly adopted for the management and storage of tailings and mine waste on gold mines in Western Australia usually results in the formation of numerous separate landforms. At the Randalls Gold Project, it has been possible to take advantage of the timing of overburden and waste removal from the open pit to create a full height tailings storage facility embedded within the waste stockpile to form a single integrated waste landform. A suitable location for waste and tailings storage was identified immediately adjacent to the open pit, and early geotechnical investigations revealed that appropriate materials are available within the pit overburden to construct engineered embankments that will safely contain the tailings. Tailings test work has indicated that the formation of a full height facility to about $20 \mathrm{~m}$ over about 5 years of production could be accommodated. Site investigation, characterisation and numerical modelling has demonstrated that seepage emanating from the landform will report to the open pit, which will act as a permanent ground water sink, thus limiting adverse impacts that are typically associated with seepage from mine waste landforms. Careful planning, scheduling, placement and treatment of waste removal ahead of mineral processing has therefore allowed for the economical development of an environmentally attractive integrated landform. Materials appropriate for the formation of a long term cover to the landform have been identified and stockpiled for use in rehabilitation and final landform protection and shaping.
\end{abstract}

\section{Introduction}

The conventional approach to the development of a tailings storage facility (TSF) on a mine property in Western Australia (as well as many other parts of the world) results in the TSF being a distinct, separate landform, often occupying many hundreds of hectares and constructed many tens of metres in height. A TSF landform of this nature is frequently characterised by long straight lines and flat surfaces. Such a TSF landform is prone to water and soil erosion, as well as medium to long term alteration through exposure to oxygen. To address these issues, mine operators typically relocate large proportions of their mine waste stockpiles, using the harder, more robust material as a component of an armouring layer to protect the TSF. The mine waste, which is commonly blasted hard rock, may be co-mingled with other soils that have been specifically stockpiled for the purpose, to form a manufactured material that is aimed at supporting vegetation growth. This invariably requires the re-handling and transportation of significant volumes of material at a cost. The approach can be moderately successful, but often fails to fully address the underlying objectives of creating a long-term safe, stable and aesthetically acceptable landform (DME, 1999).

The recent development of the TSF at Integra Mining Ltd's Randalls Gold Project in Western Australia presented an opportunity to reconsider the manner in which the TSF landform is developed. The Project is an open cut gold mine, located $65 \mathrm{~km}$ to the south-east of Kalgoorlie, and is targeted to mine over $3 \mathrm{Mt}$ of ore over a period of four years. Specific consideration has been given to the requirement for the majority of the mine overburden to be pre-stripped ahead of ore processing. The overburden comprises materials that range from oxidised to fresh rock, which affords an opportunity to specifically characterise the materials into those suitable for low permeability engineered fill, growing medium and material suitable for armouring. A single integrated waste landform (IWL) that accommodates all mine waste and tailings production has been developed. The desired completed shape of the IWL has been considered from the outset of development, so that there is minimal need to rehandle materials to create a post-mining landform that is safe, stable and 
which blends into the surrounding landscape. Creating an integrated waste landform from the outset of mining has compelling advantages over the more traditional approach of developing separate tailings and waste rock facilities. Integra Mining Ltd has recognised that these advantages have provided sufficient justification at the Randalls Gold Project to adjust the mine schedule and other significant mine infrastructure components, including the process plant location, to realise the formation of an IWL.

\section{Background}

\subsection{General}

The Randalls Gold Project (RGP) is a hard rock open pit gold mine, located approximately $65 \mathrm{~km}$ south-east of Kalgoorlie. The RGP comprises mineral resources at Salt Creek, and Maxwells and exploration prospects at Lucky Bay, Cock-eyed Bob, Mohegan, Lady Eileen and Red Dale. Figure 1 shows layout of the relevant mine infrastructure. The plant site, located near the Salt Creek Pit, will process ore from both the Salt Creek and Maxwells gold deposits. The proposed IWL lies on the east side of the broad shallow valley of the 'Salt Creek' that flows north to south, with an approximate slope of $0.13 \%$.

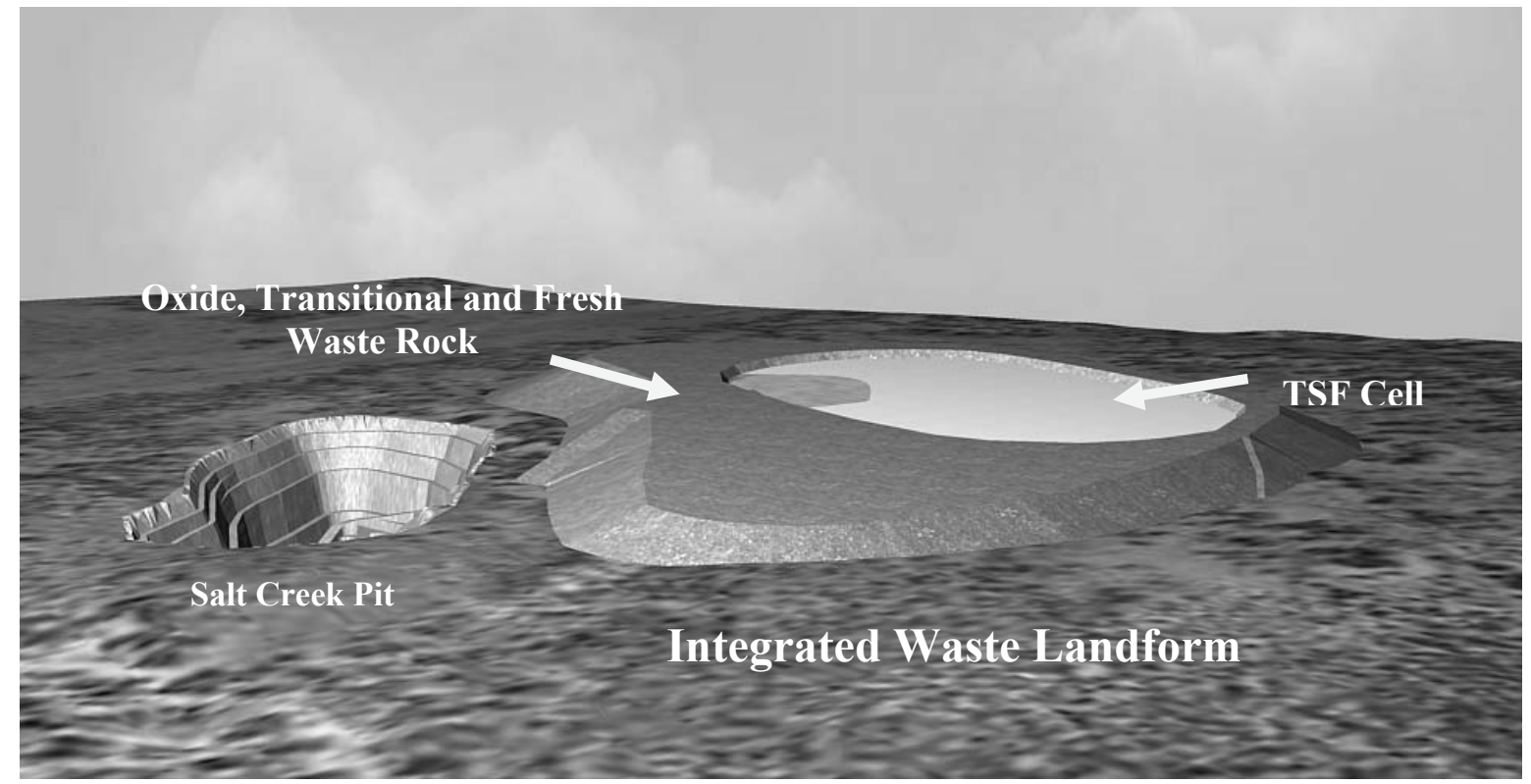

Figure 1 Layout of mine infrastructure at the Randalls Gold Project

The proposed tailings production rate for the plant will be approximately 795,000 tpa. Based on a ramp-up period of nine months and a life of mine of 4 years, the IWL has been designed to accommodate approximately $1.8 \mathrm{Mm}^{3}(\sim 3.2 \mathrm{Mt})$ of tailings solids and approximately $5.2 \mathrm{Mm}^{3}$ of waste rock.

The tailings will be pumped to the tailings storage facility as conventional slurry at a pulp density of $\sim 45 \%$ solids by mass and sequentially deposited from around the cell perimeter to maintain a supernatant pond adjacent to the access ramp. The IWL will reach a height of approximately $20 \mathrm{~m}$ above the original ground level.

\subsection{Waste rock production and properties}

Figure 2 shows the waste rock production schedule on a monthly basis. The IWL will not store waste rock from the Maxwells deposit, as this material will be placed in a separate waste stockpile closer to the Maxwells pit. 
700,000

$7,000,000$

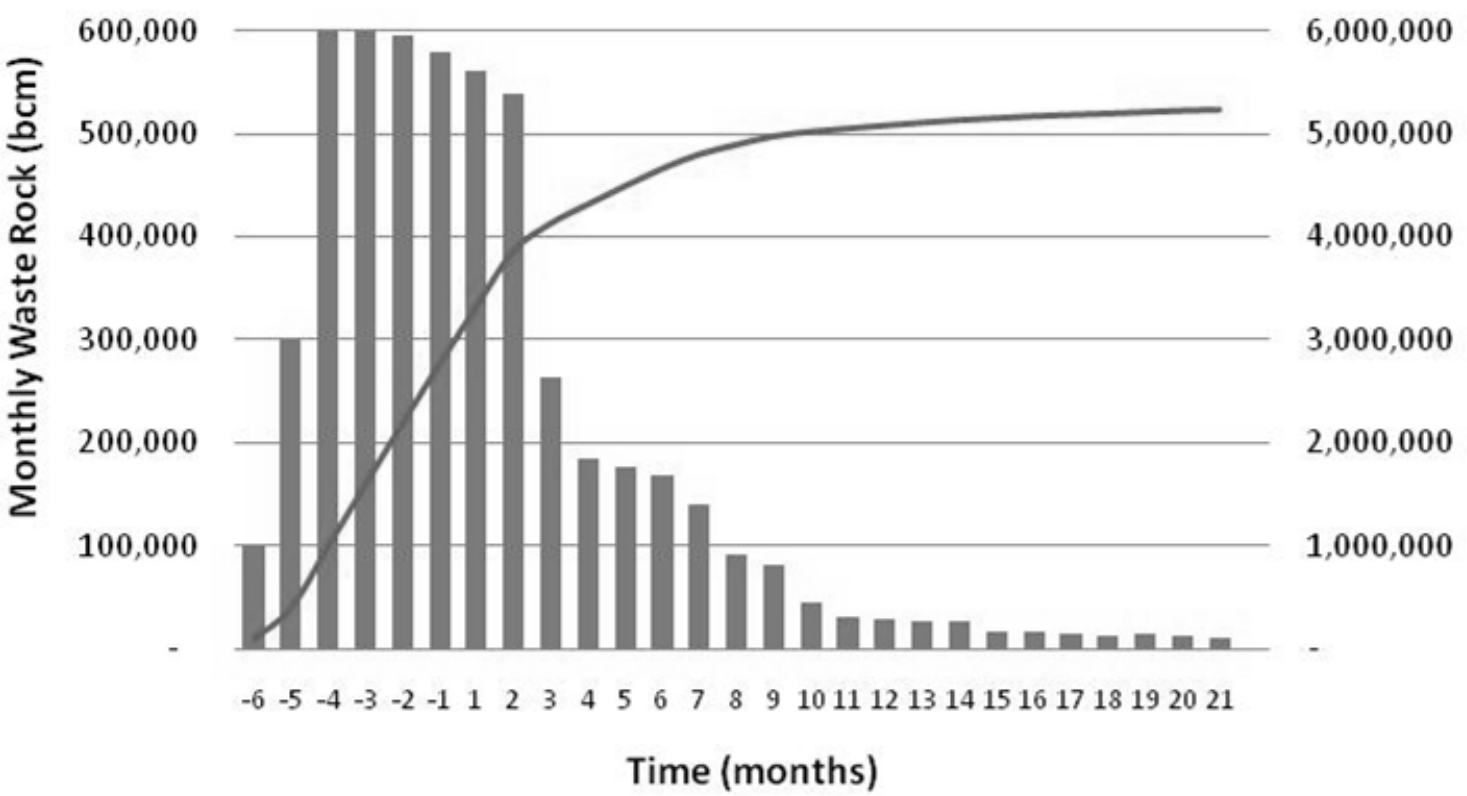

Monthly Waste Cumulative Waste

\section{Figure 2 Salt Creek waste rock production schedule}

It is evident from Figure 2 that most of waste rock will be available in the first year of pit development, with diminishing amounts (less than $200,000 \mathrm{~m}^{3}$ per month) in subsequent years. The IWL takes advantage of the abundance of overburden waste available during the early stages of mining for the construction of the facility.

Critical to the successful implementation of this concept was the availability of adequate volume of appropriate construction materials for the TSF. It was also important to understand the geotechnical properties of all the materials to be located in the IWL. The materials were broadly classified into three material types as follows.

- Oxide waste, comprising $24 \%$ of the total waste, with a majority of all oxide material available in the first year.

- Transitional material, comprising $36 \%$ of the total waste, with approximately $80 \%$ of the transitional material available in the first year.

- Fresh waste rock, comprising $40 \%$ of the total waste, with approximately $10 \%$ of the fresh material available in the first year.

Geotechnical tests indicated that the oxide waste is sandy clay and is suitable to line the upstream face of the TSF cell. The transitional material is sandy gravel and is suitable for formation of the TSF cell embankment. The fresh rock is suitable as bulk fill and armouring material.

Testing has indicated that both the Maxwell's and Salt Creek tailings have sufficient neutralising potential to prevent acidification occurring.

\subsection{Tailings production and key parameters}

The Randalls Gold Project is planned to produce at least 3.2 Mt of tailings over a production period of four years. Additional production may extend the life of the operation, and provision for additional storage of tailings has been provided for in the IWL. The waste rock stored in the IWL is unlikely to increase, as the 
additional ore will be sourced from satellite deposits that will have separate waste stockpiles located closer to the pits.

A suite of test work was carried out to provide information on the physical characteristics of the tailings and to establish appropriate design parameters. The tests indicated the tailings would have the characteristics described below.

- The specific gravity of the tailings solid particles is 2.83 , which is somewhat higher than typically encountered elsewhere in the Goldfields (based on data within the confidential internal archives of Golder Associates). This, coupled with the particle size distribution suggests that segregation across the beach is likely, assuming a discharge slurry concentration of $46 \%$ solids by mass. It is expected that a concave beach will form with a relatively steep upper beach slope and an average gradient across the beach of about $1 \%$.

- The initial settled dry density of the tailings is likely to be on the order of $1.3 \mathrm{t} / \mathrm{m}^{3}$, which will be achieved in less than half a day, suggesting that a pond residence time in the order of 24 hours should be sufficient to allow clear water to be returned to the plant.

- The air-dried dry density of the tailings following simulated summer and winter drying conditions is approximately $1.85 \mathrm{t} / \mathrm{m}^{3}$ and subsequent loading of the tailings will only achieve a minimal increase in the density of the tailings through consolidation to $1.88 \mathrm{t} / \mathrm{m}^{3}$.

- Segregation across the beach, coupled with a relatively high rate of rise of $4 \mathrm{~m} /$ year, will likely reduce the dry density achieved on the surface of the beach from the ideal conditions represented in the laboratory, leading to an expectation that the tailings will achieve an average in situ dry density of $1.75 \mathrm{t} / \mathrm{m}^{3}$.

- The density achieved through evaporative desiccation (air drying) is expected to be equivalent to loading the tailings to a depth of $20 \mathrm{~m}$. As a result, the majority of consolidation (and hence settlement) is expected to occur during and immediately following deposition.

- Estimates of the time required for the tailings to consolidate after deposition is complete indicate that a $20 \mathrm{~m}$ column of tailings undergoing two-way drainage would require about six months achieving $95 \%$ consolidation. This estimate assumes that the tailings are placed in a single column equivalent to the depth of the cell over a short time period, and hence the time to consolidate is considered to be conservative. It is anticipated that closure of the TSF cell will be able to commence within a few months after deposition is complete.

\section{$3 \quad$ Approach and design evolution}

The waste management concept adopted for the Project was to develop an Integrated Waste Landform (IWL) that accommodates the mill tailings and mine overburden and waste materials in a single landform. The IWL has been designed to accommodate the tailings produced from ore processing in a single dedicated cell, or tailings storage facility (TSF), constructed from, and ultimately encapsulated by, other mine waste materials. The pre-stripped oxide waste from the open pit has been used as engineered fill for the TSF perimeter embankment, and traffic-compacted transition material was placed as supporting embankment fill material. Subsequent waste materials that will be excavated from the pit as the mine evolves will be strategically placed in the IWL to create a landform that meets the project objectives, which include erosion resistance, ability to support vegetation and visual amenity.

The adopted approach provides an efficient use of the mine waste, whilst minimising the disturbed footprint occupied by the mine waste materials, and facilitates the development of an aesthetically acceptable and long-term stable final landform.

During the early stages of design, a concept was proposed that required the development of two TSF cells. TSF Cell 1 was a starter cell, envisaged to be constructed as a side-hill impoundment, thus taking advantage of the natural slope to reduce the amount of embankment fill required for construction. Cell 1 provided 8 months of tailings storage (approximately $0.3 \mathrm{Mm}^{3}$ ). This would have provided sufficient time to construct Cell 2, based on the required embankment quantity and mine waste production schedule. The large proportion of mine waste produced in the first year of operation would have been used to full advantage by 
constructing Cell 2 immediately adjacent to Cell 1, while Cell 1 received the first eight months of mill tailings. Cell 2 would have been used to accommodate the balance of the tailings produced over the mine life $\left(2.2 \mathrm{Mm}^{3}\right)$. Cell 2 was planned to be a single stage (full height) TSF, obviating the need for wall raises during operation. The embankment around Cell 2 was planned to be approximately $17 \mathrm{~m}$ high, having a horizontal crest. Figure 3 shows a simplified layout of the early concept.

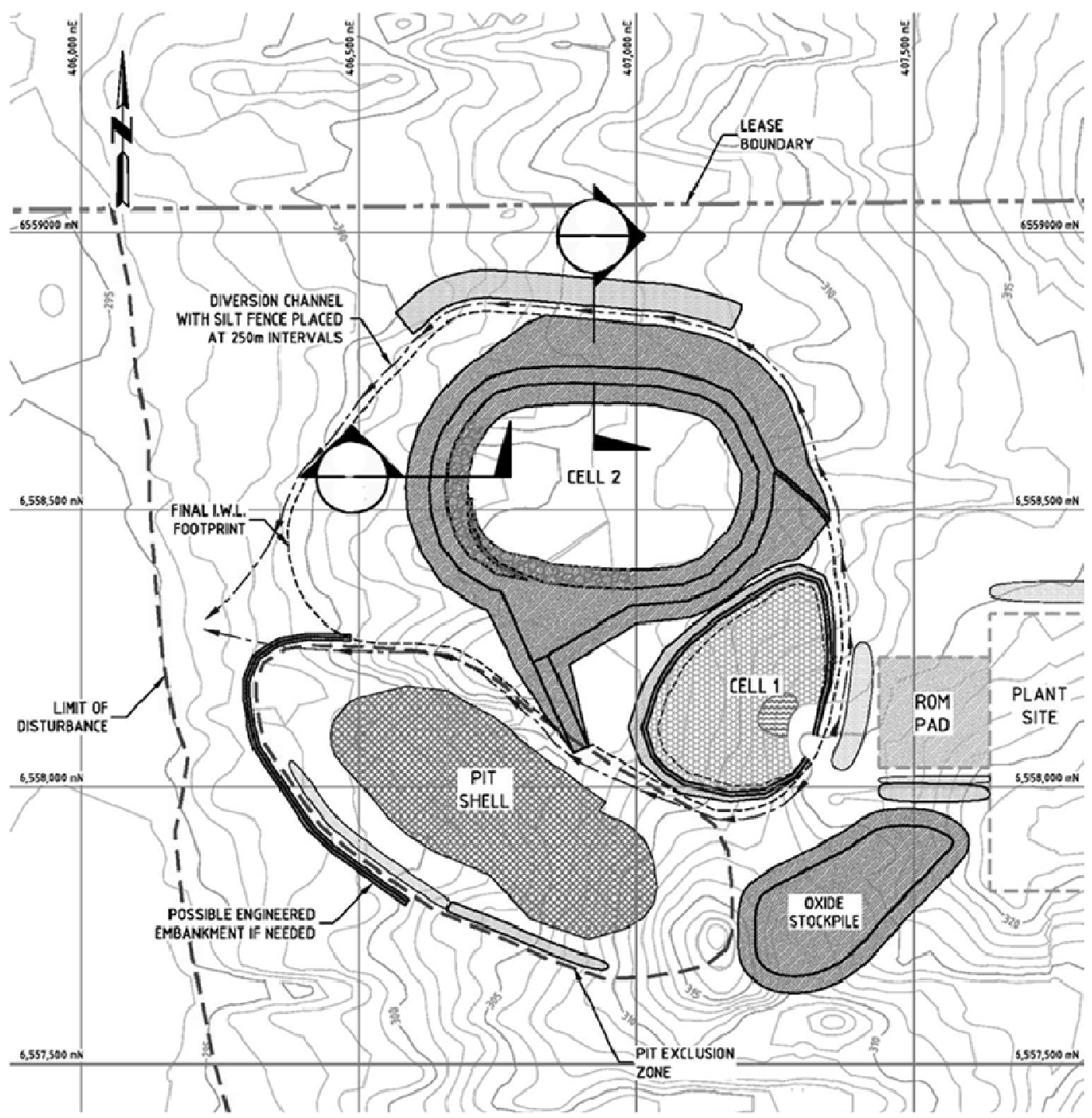

Figure 3 Early concept for the IWL, containing two TSF cells

After further consideration of this early concept, a cost, risk and environmental trade-off study revealed that it would be beneficial to avoid construction of two TSF cells and to provide only one TSF cell within the IWL. This was achieved by accelerating the placement of engineered fill through the use of scrapers.

As the IWL concept was being finalised, the following items were identified as critical to success of the project:

- The ability to control when each type of construction material was excavated out of the pit, to meet the TSF's construction needs.

- The capacity of the selected mining contractor to construct an engineered earth structure.

As these concerns were identified early in the project development, it was understood that they would need to be addressed and managed prior to construction commencement. IML took the following measures to mitigate these concerns: 
- IML hired a full time quality assurance inspector to be on site during the TSF construction. One of the key responsibilities of the inspector was to coordinate daily with the mining contractor to manage the material type and quantity that was being excavated out of the pit. It was agreed that the mining contractor may have to alter its excavation pattern to meet the needs of the TSF construction.

- IML hired a separate earthworks contractor to construct the TSF. The contractor selected to construct the TSF had specific experience in the construction of engineered earth structures.

During the course of the TSF construction, it was the responsibility of the mining contractor to excavate, haul and dump the TSF/IWL construction materials at the locations requested by the earthworks contractor. It was the responsibility of the earthworks contractor to spread, moisture condition, and compact the construction materials in accordance with the specifications.

\section{$4 \quad$ The adopted solution}

\subsection{Layout}

The solution that was adopted resulted in an IWL design is illustrated on Figure 4.
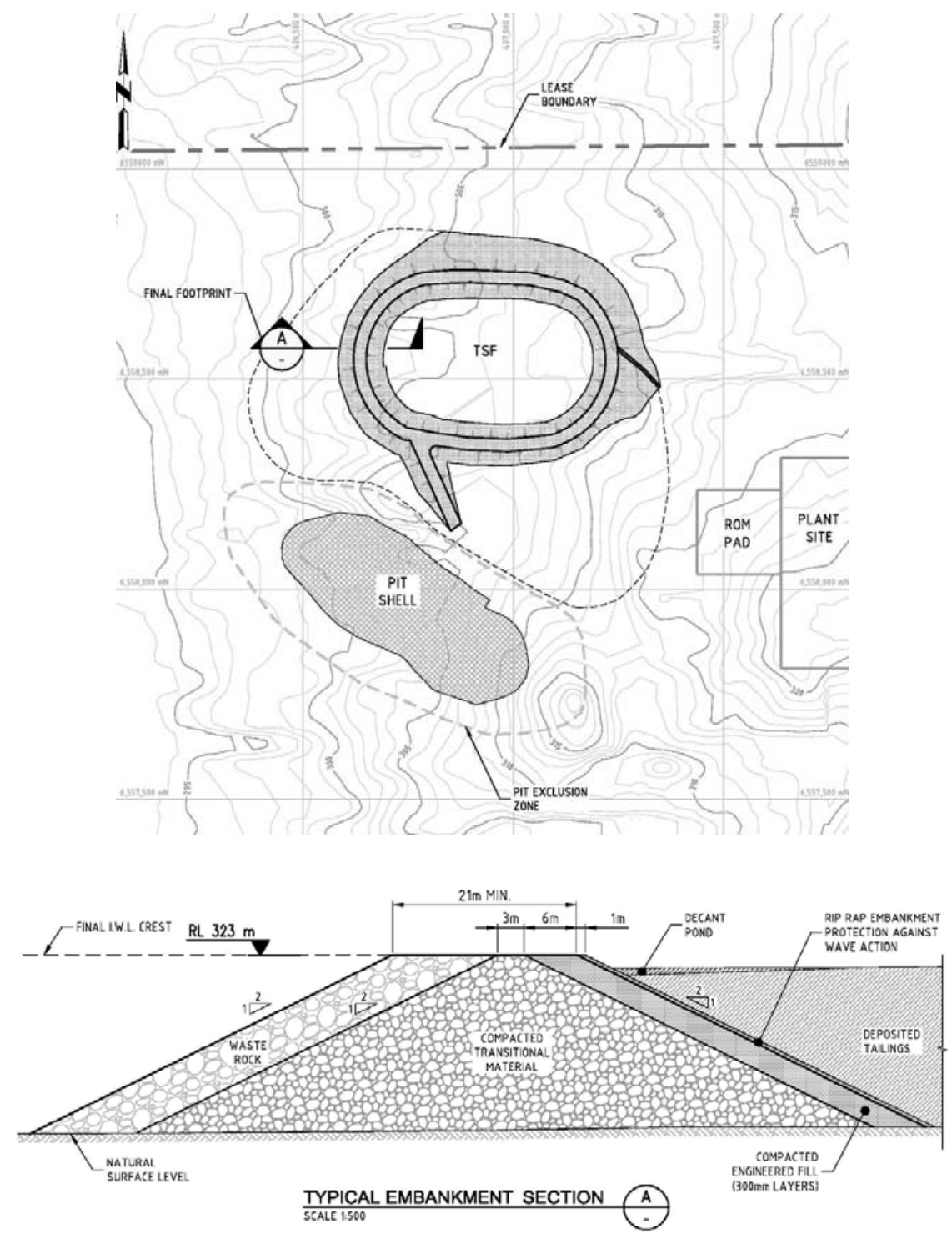

Figure 4 Adopted solution for the IWL, containing one TSF cell 


\subsection{Site selection and investigation}

The IWL is located adjacent to the open pit, but strategically placed to be outside of the potentially unstable (exclusion) zone (DoIR, 1997). This location was primarily based on the economical haul distance for the waste materials and pit ramp locations, but also took cognisance of site topography, the hydrogeological and geotechnical conditions of the site, surface drainage, and the ability to locate the process plant in close proximity. The process plant was located as close as practicable to the IWL to minimise piping and pumping costs. A key driver in the design was also the measures that needed to be considered to manage seepage emanating from the IWL.

To this end a geotechnical and hydrogeological investigation of the site was carried out, which included:

- Excavation of 22 test pits ranging in depth from 0.9 to $3.0 \mathrm{~m}$.

- Logging and photographing the test pits in accordance with the unified soil classification system.

- Collection of representative samples from select test pits for material index property testing.

- Drilling of six reverse circulation boreholes ranging in depth from 10 to $42 \mathrm{~m}$.

- Logging of the boreholes on the basis of returned cuttings.

- Conversion of five boreholes into groundwater monitoring wells.

- Hydraulic testing of all six boreholes

- In situ testing to measure the hydraulic conductivities of the subsurface materials.

The investigations indicated that the proposed IWL is generally underlain by clayey sands of low to medium plasticity. The test pits indicated some areas within the footprint of the IWL that comprise sandy clay, which may suggest some minor settlement may occur under loading, but affords some resistance to seepage. A representative geological section through the IWL site is illustrated on Figure 5.

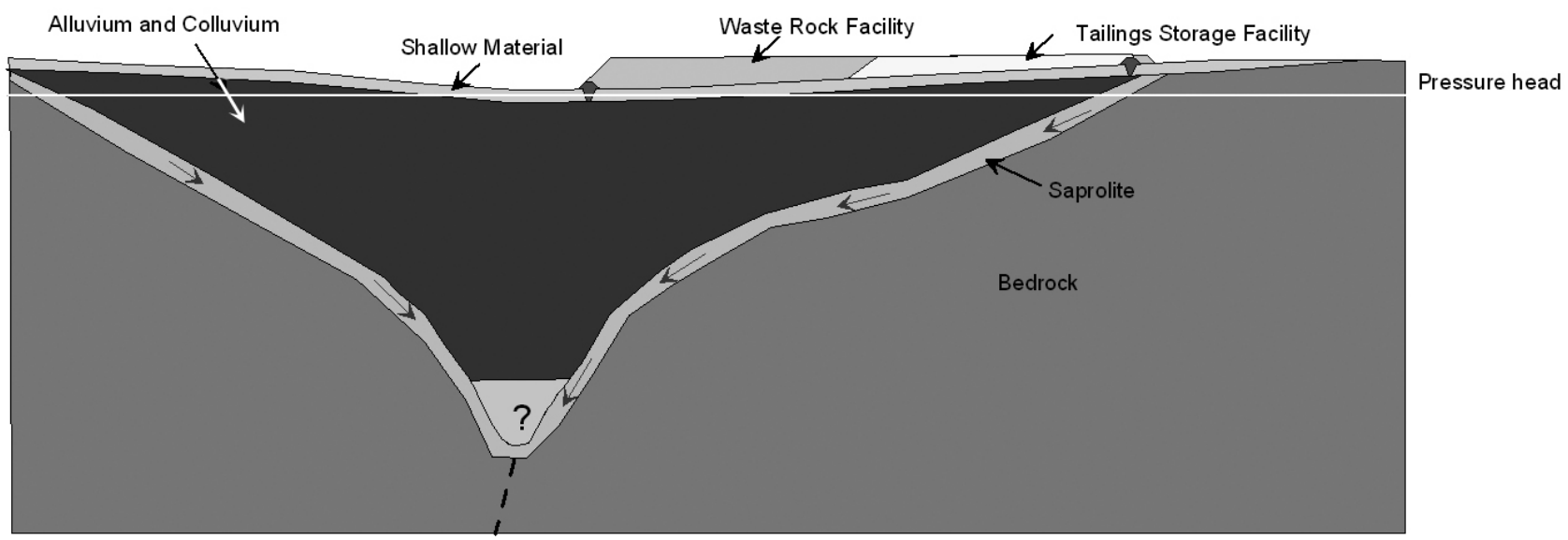

\section{Figure 5 Representative geological section through the IWL site}

The hydrogeological investigations of the area indicated hydraulic conductivities of the foundation materials ranging from $1 \times 10^{-5}$ to $6 \times 10^{-8} \mathrm{~m} / \mathrm{s}$. The highest hydraulic conductivity appears to be associated with either saprolite or coarse grained transported material, which occurs on the interface between the fine-grained sediments and the bedrock. The boreholes near the proposed pit show variable hydraulic conductivities ranging from $2 \times 10^{-8} \mathrm{~m} / \mathrm{s}$ to $1.15 \times 10^{-6} \mathrm{~m} / \mathrm{s}$, interpreted to be dependent upon the percentage of clay and gravels present. Hydraulic tests, targeting the underlying unweathered granitoid rock indicated a low permeability rock $\left(2 \times 10^{-8} \mathrm{~m} / \mathrm{s}\right)$. It was concluded that groundwater flow is mostly associated with the saprolite or coarse grained transported material occurring between the bedrock and overlying fine-grained sediments.

These values were used to develop a conceptual hydrogeological model and were incorporated into a seepage and groundwater response model developed for the IWL. The main objective of the model was to assess 
whether seepage from the IWL would flow towards the open pit during both the operational and post-closure phases. This analysis was carried out for two conceptual closure designs namely 'dome' and 'dish' designs.

The post-closure pit lake water balance model demonstrated that water levels in the post-closure pit lake would be lower that the surrounding groundwater levels. This means that water in the pit lake would remain a hydraulic sink, because evaporation rates are significantly higher than water inflows into the lake. Because the water levels in the pit lake will remain lower than the surrounding groundwater levels, a permanent cone of depression will remain around the pit lake. Seepage flowing through the floor of the IWF, which is situated in this cone of depression, will eventually flow towards the pit lake. Figure 6 indicates the results of the seepage modelling.

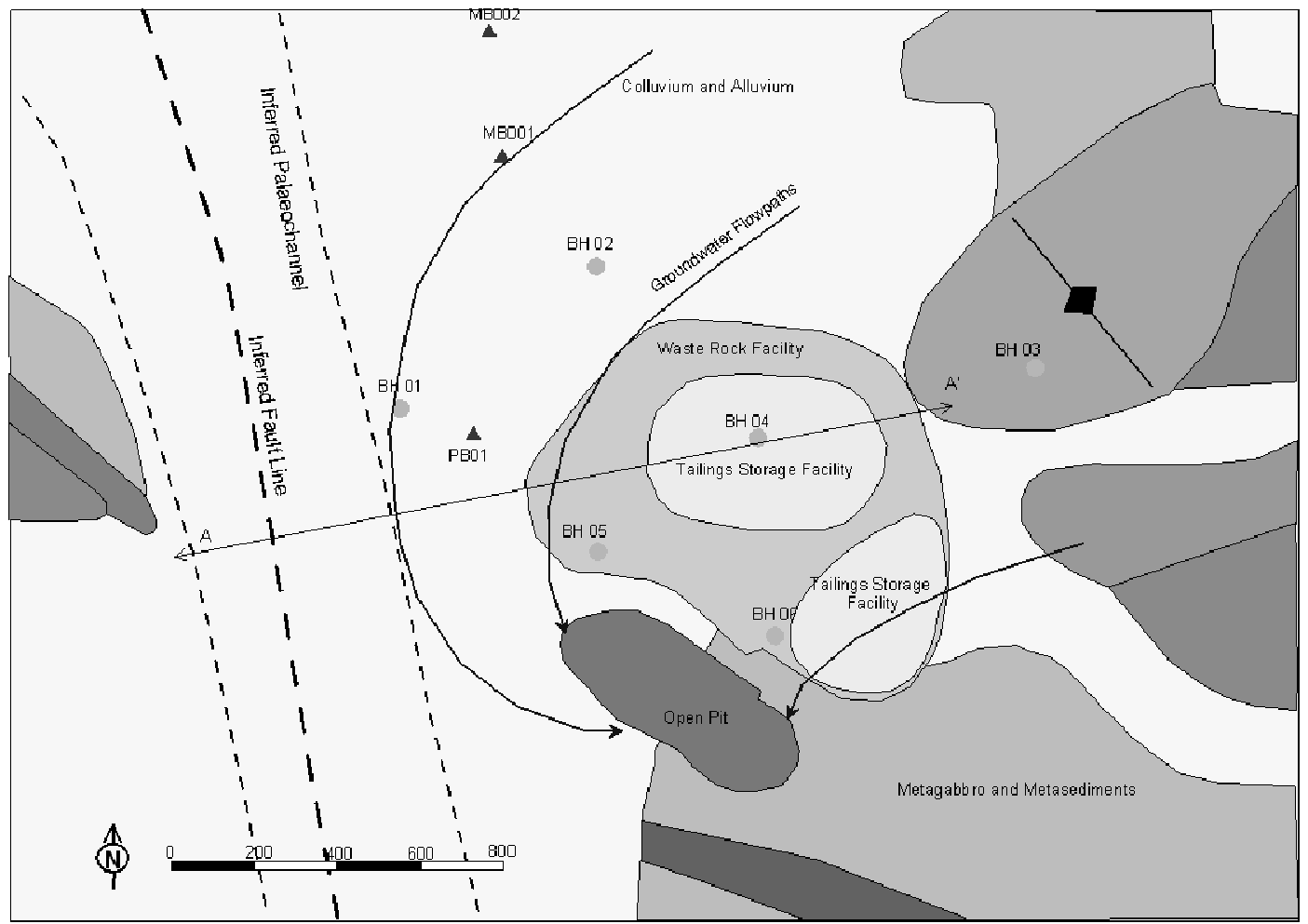

Figure 6 Results of seepage modelling indicating seepage flow discharge to the pit

The outcome of the modelling demonstrated that the location of the IWL allows the limited volume of seepage water flowing through the floor of the facility to be captured in the mine pit, from where it will be evaporated. This confirmed the suitability of its location and allowed the IWL design to be incorporated into the mine plan from the early stages of mine design. The importance of the location of the IWL to the project success was identified early in the process. It was important that the IWL was located near the mine pit to minimise the haul distance. After the IWL site was established, the plant and other infrastructure were strategically located within the mine lease to best suit the locations of the mine pit and the IWL.

Strategically located groundwater monitoring bores will be used throughout the operational period and beyond to monitor the groundwater response and to check that it is consistent with expectations.

\subsection{Tailings deposition management}

The single TSF cell will accommodate the scheduled life of mine tailings production of $4.33 \mathrm{Mt}$ tailings solids (occupying a volume of about $2.5 \mathrm{Mm}^{3}$ ). Provision has been made to accommodate additional tailings, should the need arise.

Tailings deposition is managed to maintain the supernatant water pond on the TSF at a location against the perimeter embankment, close to the access ramp into the TSF. This facilitates removal of decant water for reuse in the plant, as the supernatant liquor is pumped from a pontoon tethered to the access ramp. This is analogous to the commonly adopted approach for in-pit tailings management and the Randalls TSF therefore 
operates in a similar manner to an in-pit TSF. The active tailings deposition is, however, cycled along the perimeter embankment to improve tailings drying and consolidation, a measure that is uncommon in in-pit tailings management.

The adoption of a full height embankment for the TSF within the IWL has allowed for some relaxation in the rate of rise of the tailings that is normally considered to facilitate pore pressure dissipation. Conventional gold TSFs in Western Australia generally need to limit the rate of rise to less than approximately $2 \mathrm{~m} / \mathrm{yr}$, in order to allow the tailings to develop adequate strength to allow for upstream raising of the TSF wall. To ensure a sufficiently slow rate of rise, the TSF footprint must be enlarged. The TSF at the Randalls Project was, however, designed for an approximate $4 \mathrm{~m} / \mathrm{yr}$ rate of rise, which reduced the footprint of the TSF by approximately half of that occupied by a conventional TSF. The benefits of the smaller footprint are the reduction of up-front bonding cost, as well as reducing rehabilitation and closure costs.

An additional benefit of the relatively high rate of rise of the tailings is that the tailings beaches will remain saturated prior to being covered with fresh tailings. This will limit the potential for oxidation of sulphides, and thus lower the probability of acid mine drainage occurring to an insignificant level.

\subsection{Surface water management}

To minimise the possibility of surface flow from Salt Creek watercourse impeding upon the proposed IWL, hydrological and hydraulic analyses of the Salt Creek watercourse were undertaken. The watercourse was modelled for various design flood discharges to evaluate the flood risk at the site.

The proposed surface water management plan is based on the following components:

- Estimating design flood discharges for Salt Creek watercourse at a location immediately adjacent to the IWL for a range of annual recurrence intervals (ARI) from 10 to 100 years and a preliminary estimate of the PMF.

- Diverting runoff from the IWL, topsoil and oxide stockpiles, and the plant facility, via a series of channels to discharge into the Salt Creek watercourse.

Surface water runoff in the Salt Creek watercourse naturally flows in a southerly direction and terminates in Lake Randall, a playa lake some $6 \mathrm{~km}$ south of the IWL. The Salt Creek catchment area is estimated to be approximately $297 \mathrm{~km}^{2}$ as shown in Figure 7.

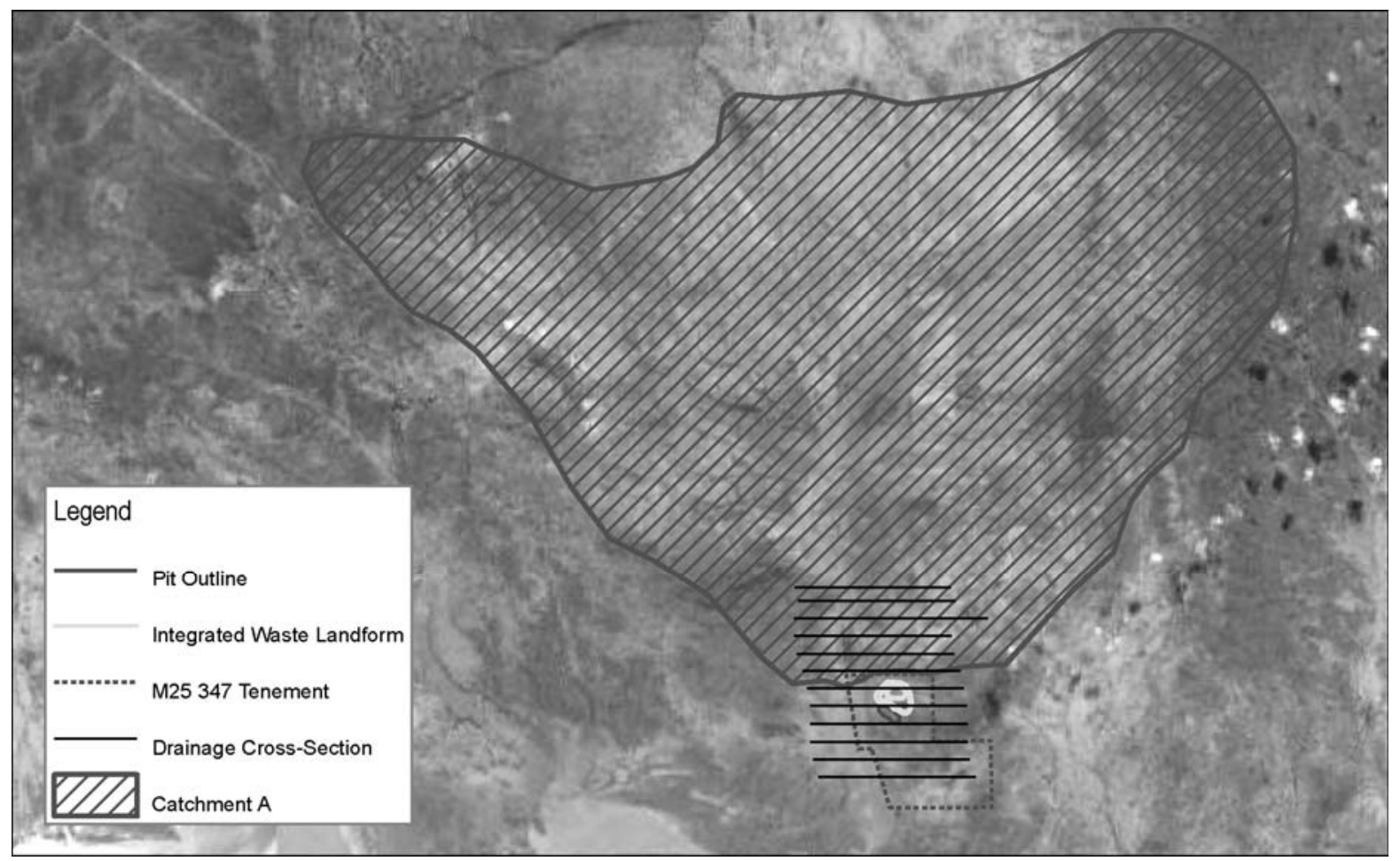

Figure 7 Surface water catchment area 
Based on the results of the hydrological and hydraulic analyses, a surface water management plan was developed for the IWL to manage the 100 year ARI storm event. This involved constructing diversion channels around the IWL to convey captured runoff into Salt Creek as shown in Figure 8. Post-construction modelling of a levee embankment extending around the project site indicate flood levels are unlikely to vary significantly from those estimated to occur under existing conditions. Therefore, flood protection measures are not considered essential for ARI floods up to the 100-year event.

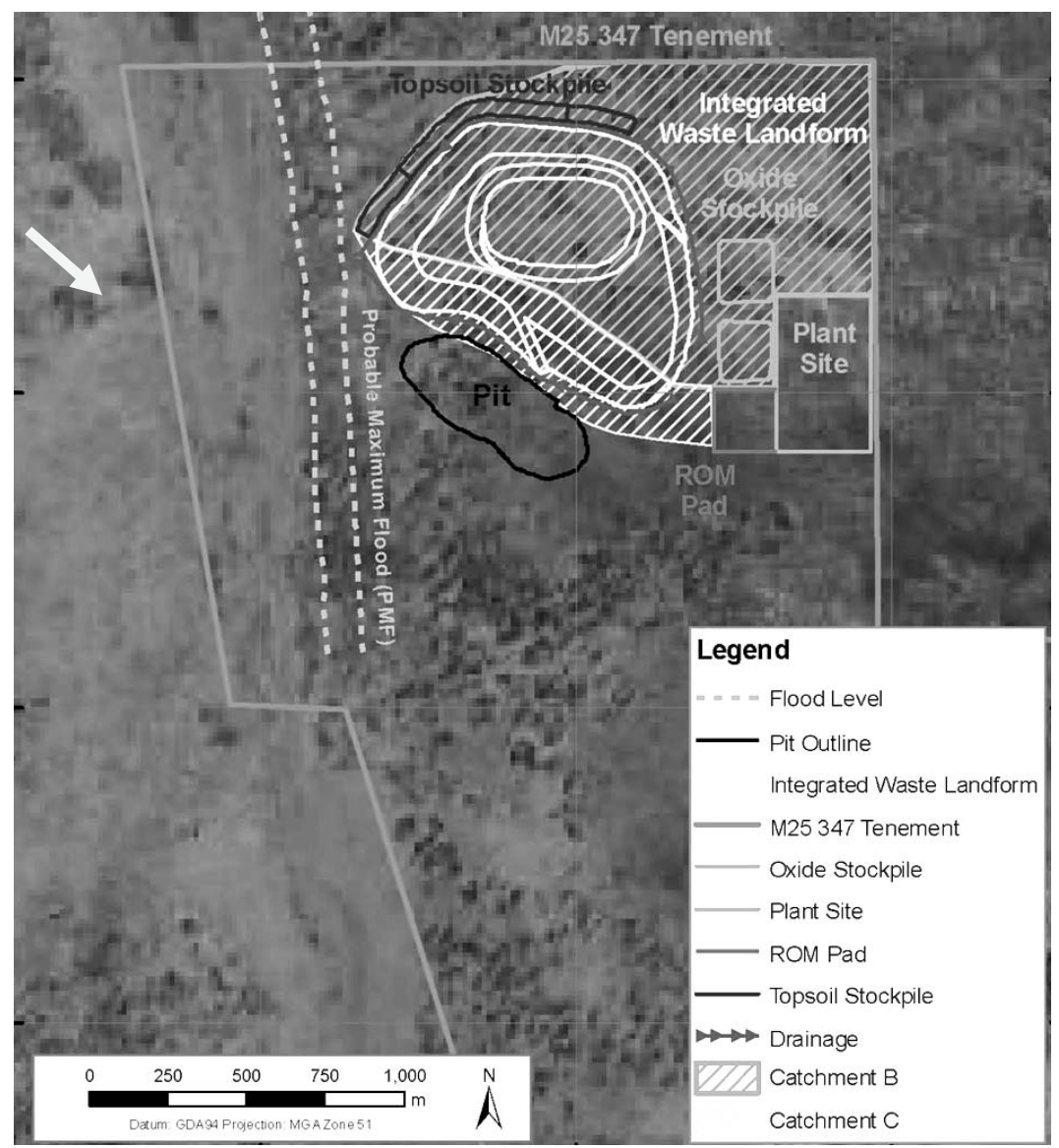

\section{Figure 8 Surface water management plan}

\subsection{Slope geometry}

The upstream embankment batters are constructed to a slope of $2 \mathrm{H}: 1 \mathrm{~V}$. The portion of the upstream embankment that is in direct contact with the supernatant pond is protected with a layer of non-woven geofabric, overlain by rock armouring to minimise the potential for erosion and to improve the clarity of the supernatant water.

The downstream embankment batters are constructed in a flattened ' $\mathrm{S}$ ' shape, resulting in an average slopes of $5 \mathrm{H}: 1 \mathrm{~V}$. Figure 9 indicates a typical section through the outer slope. The external slope profile is designed to mimic natural slopes and reduce the potential for the formation of erosion gullies. By constructing the outer embankment of the IWL with waste rock and adjusting the widths of the benches during placement, the need for double-handling to achieve the final profile has been significantly reduced. Moreover, this careful planning of the final landform geometry has allowed progressive closure of the IWL to commence, even prior to initial tailings production. 


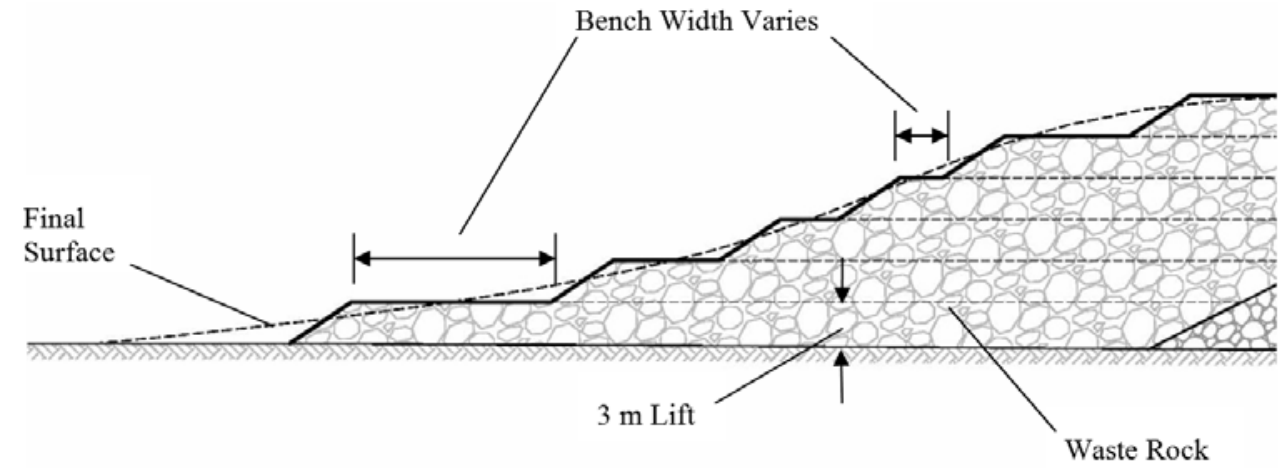

Figure 9 External slope geometry of IWL - during and post-construction

The external slopes of the IWL will be revegetated. The slope treatment is likely to comprise a blend of materials that will incorporate topsoil that was stripped from the footprint and stockpiled for this purpose ahead of construction.

To reduce the volume and intensity of water flow on the downstream slopes, the final landform will not encourage shedding of incident rainfall from its upper surface, as shown on Figure 10.

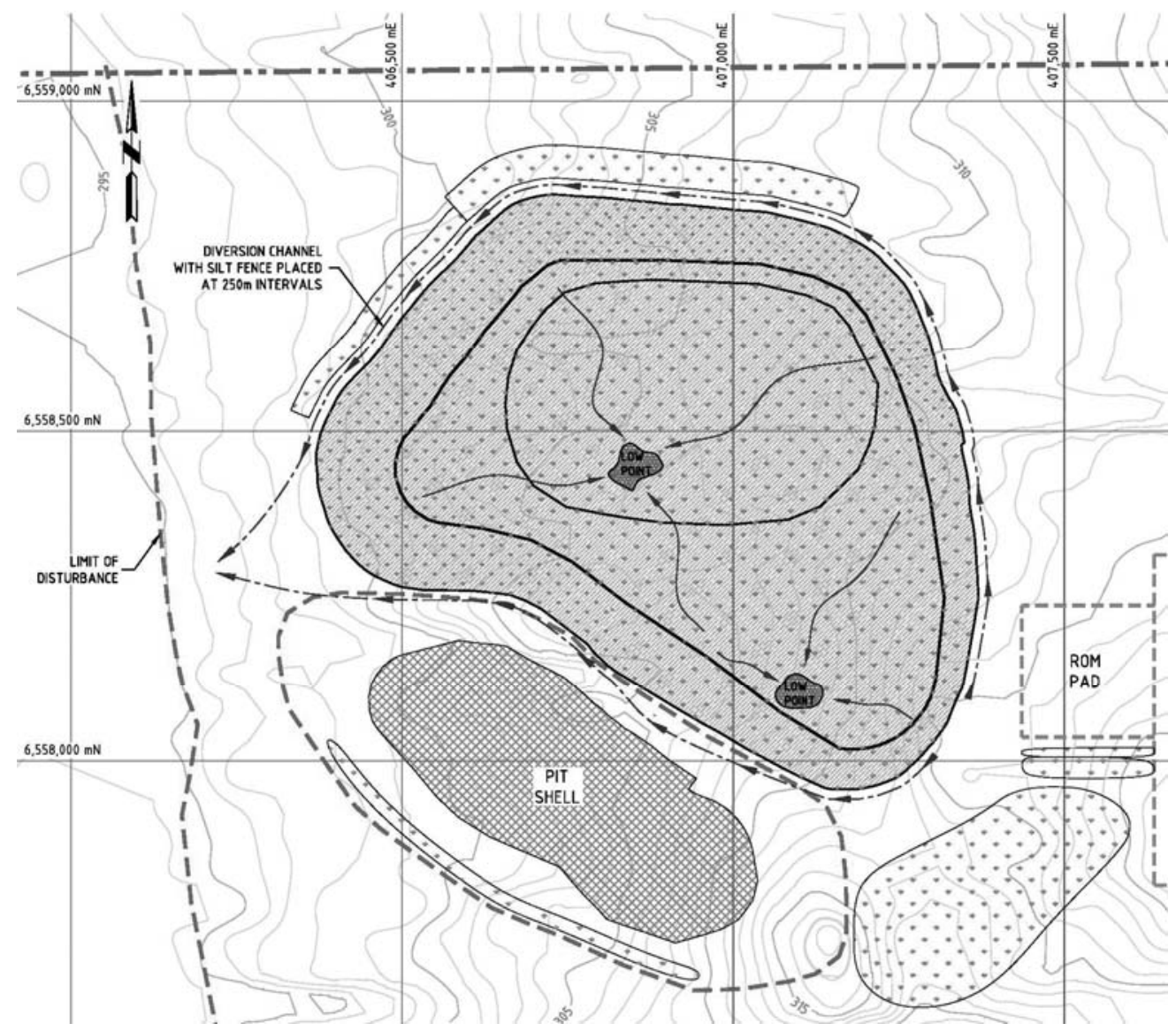

Figure 10 Water management on final surface of IWL

\subsection{Geotechnical stability}

Stability analyses of the proposed IWL embankment were carried out using the commercially available software code SLIDE, which adopts a limit equilibrium approach (Morgenstern-Price method) to stability analyses. The TSF/IWL is classified as Category 1, Significant Hazard in accordance with the Guidelines on the Safe Design and Operation Standards for Tailings Storage (DME, 1999) (formerly, Department of Minerals and Energy, now the Department of Mines and Petroleum). The following minimum acceptable 
Factors of Safety (FoS) are based on the requirements set down by ANCOLD (ANCOLD, 1999) and are considered appropriate for the IWL:

- Steady state static loading conditions (no seismic), $\mathrm{FoS}=1.5$.

- Operating base earthquake (OBE) conditions, $\mathrm{FoS}=1.1$.

- Maximum design earthquake (MDE), $\mathrm{FoS}=1.0$.

The results of the stability analyses carried out under static and dynamic conditions are summarised in Table 1 below.

Table 1 Stability results under static and dynamic conditions

\begin{tabular}{lcc}
\hline Conditions & $\begin{array}{c}\text { TSF Post- } \\
\text { Construction }\end{array}$ & $\begin{array}{c}\text { TSF During } \\
\text { Construction }\end{array}$ \\
\hline Static & 2.03 & 2.76 \\
OBE & 1.57 & 2.10 \\
MDE & 1.53 & 2.09 \\
\hline
\end{tabular}

The results indicate that the estimated FoS exceed the ANCOLD guidelines for both the static and dynamic cases. Major slope instability of the IWL embankment is therefore unlikely to occur, even under the expected maximum earthquake loading conditions.

\subsection{Risk assessment}

A fault mode and effects analysis (FMEA) was carried out to assess the potential for failure of the IWL and the likely consequences. This approach is consistent with AS/NZS 3931:1998. The FMEA technique was adopted to assess whether there is a need to carry out more rigorous analyses and this technique relies upon the subjective identification and assessment of potential failure mechanisms that could result in a failure of the IWL.

Five potential failure mechanisms were identified and the likelihood of occurrence of each event was ranked on a scale of 1 to 5 , where 1 is a negligible likelihood and 5 is an almost certain likelihood. The potential for each failure event to result in a release of tailings and/or water from the IWL was also ranked on a scale of 1 to 5 , where 1 is little to no potential for release and 5 is a near certain chance that a release would result. The risks of each failure mechanism resulting in a failure with unacceptable consequences were computed as the product of these two assigned values as shown in Table 2.

\section{Table 2 Assigned risk study}

\begin{tabular}{llccc}
\hline Case & Failure Mechanism & $\begin{array}{c}\text { Likelihood of } \\
\text { Occurrence }\end{array}$ & $\begin{array}{c}\text { Potential to Result } \\
\text { in a Flow Failure }\end{array}$ & Product \\
\hline A & Overtopping of an external embankment & 2 & 2 & 4 \\
B & Slope failure of the external embankment & 1 & 4 & 4 \\
C & Piping erosion failure through external & 2 & 3 & 6 \\
& embankment & & 2 & 2 \\
D & Progressive sloughing due to seepage & 1 & 1 & 1 \\
E & $\begin{array}{l}\text { Erosion of the embankment due to pipe } \\
\text { breakage or rainfall }\end{array}$ & 1 & & \\
\hline
\end{tabular}

These values have been entered into the risk-rating matrix presented below. The assigned risks for each of the potential failure mechanisms identified above are indicated. 
Table 3 Risk matrix

\begin{tabular}{|c|c|c|c|c|c|c|}
\hline \multirow[b]{2}{*}{$\begin{array}{l}\text { Likelihood of } \\
\text { Occurrence }\end{array}$} & & \multicolumn{5}{|c|}{ Potential to Result in a Failure } \\
\hline & & $\begin{array}{c}\text { Low } \\
\text { (1) }\end{array}$ & $\begin{array}{c}\text { Low to } \\
\text { Moderate } \\
(2) \\
\end{array}$ & $\begin{array}{c}\text { Moderate } \\
\text { (3) }\end{array}$ & $\begin{array}{c}\text { Moderate } \\
\text { to High } \\
(4)\end{array}$ & $\begin{array}{c}\text { High } \\
\text { (5) }\end{array}$ \\
\hline \multicolumn{7}{|c|}{ Almost Certain (5) } \\
\hline Likely & (4) & & & & & \\
\hline \multicolumn{7}{|l|}{ Moderate } \\
\hline \multirow{2}{*}{$\begin{array}{l}\text { Unlikely } \\
\text { Rare }\end{array}$} & (2) & & $\mathbf{A}$ & $\mathrm{C}$ & & \\
\hline & (1) & $\mathbf{E}$ & D & & B & \\
\hline & vel: & Extreme & High & Moderate & Low & \\
\hline
\end{tabular}

It is evident from Table 2 and the risk matrix presented in Table 3 that:

- there is no entry in the 'extreme' or 'high' risk zones of the matrix

- there are two entries that are in the 'moderate' risk zone

- there are three entries in the 'low' risk zone

- the average risk rating is approximately 3.7 (the maximum possible average risk rating is 25 and the minimum is 1).

The risk of a release of tailings and/or water from the proposed IWL at the Randalls Project is therefore considered to be low. As no high or extreme risks were identified by the FMEA, it was considered unnecessary to carry out a more rigorous dam break analyses. The overall risks are considered to be as low as reasonably practicable and the IWL does not pose a risk of large scale release of tailings.

\subsection{Seepage management}

Section 4.2 describes that a seepage model was developed, which demonstrated that seepage from the TSF will migrate into the pit during the mining phase and through post-closure. The model was used to simulate seepage flows up to 200 years after closure of the mine. The water level within the open pit is predicted to remain below the natural groundwater table elevation through this period and beyond, indicating that the pit will act as a permanent groundwater sink. In this role as a terminal evaporative sump, groundwater within the cone of depression created by this sump will migrate towards the open pit. The hydraulic gradients created by the evaporative sump will assist in drawing seepage emanating from the IWL towards the open pit.

It was not necessary (in fact, it would have been counter-productive) to treat the foundation of the IWL in an attempt to achieve a lower permeability of the near-surface soils (DME, 2000). This would encourage outward migration of seepage flow, rather that the preferential flow direction towards the open pit. No specific measures to control seepage were considered to be required, although provision has been made to install a shallow seepage collection drain close to the toe of the IWL if unexpected seepage were to emerge from the toe during operations.

\subsection{Possible facility expansion}

The development of additional satellite pits may increase the life of the Randalls Project. Current indications suggest that Integra Mining Ltd will complete mining the Salt Creek Pit (immediately adjacent to the IWL) in the second year of operation. As is currently the case with the Maxwells Pit, waste rock from satellite pits will be stored in separate stockpiles closer to the satellite pits. It is therefore unlikely that there will be additional waste rock available to increase the capacity of the IWL. However, as the process plant is located near the IWL there is a potential that additional tailings will need to be stored in the IWL. It is envisaged that 
the embankments could be raised by approximately $5 \mathrm{~m}$ through centreline raising and narrowing the crest width. Additional tailings storage capacity may also be available in the mined out Salt Creek Pit.

\section{$5 \quad$ Conclusions and key learnings}

The Randalls Gold Project has provided an opportunity to develop an integrated waste landform that accommodates all the mine waste in a single storage facility. This is a significant departure from conventional practice, whereby the tailings storage facility and the mine waste stockpiles are typically evolved as separate structures. The formation of the IWL at the RGP provides numerous advantages over the more conventional approach, including the following:

- The IWL will occupy a reduced disturbed footprint, compared to that required to accommodate separate tailings and waste facilities, which reduces bonding costs and long term environmental impacts.

- Significantly more robust outer embankments are provided to the TSF, which decreases the risks of inadvertent discharge of tailings to the external environment, over the short and the long term.

- The final landform will blend more readily into the natural landscape, be less prone to releasing sediments through erosion and capable of limiting the impacts of seepage discharges to an area that is already disturbed through mining activity.

- Progressive rehabilitation of the landform will accelerate the release of bond monies and decrease the overall cost of rehabilitation, as the need for double-handling of materials is significantly reduced.

- The ability to progressively re-vegetate the surface of the IWL will reduce dust emissions and the potential for erosion of the outer surfaces.

The formation of an IWL was made possible through a number of key site characteristics and strategic decisions made by Integra Mining Ltd.

- Possibly the most significant feature of this project in relation to other projects of a similar nature and location is the waste schedule, which indicates that the majority of the mine waste is stripped from the pit ahead of commissioning the process plant. This was further improved through the use of scrapers to accelerate the placement of engineered fill in the TSF embankments. This allowed sufficient time for a single cell TSF to be completed to full height between pit overburden stripping and commissioning of the process plant.

- A second important feature of this project that allowed the IWL to be developed in this manner is the hydrogeology, which allows seepage water emanating from the IWL to flow to the mine pit in perpetuity, from where it will be evaporated. This is a significant environmental benefit, as management of long term discharge from the TSF after mine closure is frequently a major cost impediment to mine owners.

- A further (fortunate) feature of the project was the suitability of the mine waste materials for use as low permeability engineered embankment fill, bulk fill and erosion protection.

- In addition, the tailings properties at the Randalls Gold Project allow for a rate of rise of $4 \mathrm{~m} / \mathrm{year}$, assuming that a full height embankment is built to contain the tailings. This is somewhat greater than the rate of rise typically adopted in the Goldfields of Western Australia, and allows the tailings footprint (and hence construction costs) to be further reduced.

Perhaps the most significant aspect that allowed this innovative design to be realised, however, was the environmentally responsible approach taken by Integra Mining Ltd from the outset of project development. Every practicable effort was made throughout the Project by IML to encourage the formation of a low cost, environmentally attractive and long-term sustainable waste management facility. 


\section{Acknowledgement}

The authors would like to thank the directors of Integra Mining Ltd for permission to publish and present this paper.

\section{References}

Australian National Committee on Large Dams (ANCOLD) (1999) Guideline on Tailings Dam Design, Construction and Operation, October.

Department of Industry and Resources (DoIR) (1997) Safety Bund Walls Around Abandoned Open Pit Mines, Department of Industry and Resources, Western Australia.

Department of Minerals and Energy (DME) (1999) Guidelines on the Safe Design and Operating Standards for Tailings Storage, Department of Minerals and Energy, Western Australia.

Department of Minerals and Energy (DME) (2000) Water Quality Protection Guidelines No. 3, Mining and Mineral Processing, Liners for Waste Containment, Department of Minerals and Energy, Western Australia. 
